\title{
E-COMMERCE EXPERIENCES IN THE REAL ESTATE INDUSTRY. A PRELIMINARY STUDY IN REGIONAL QUEENSLAND.
}

\author{
Diana Gray \\ Jeanette Van Akkeren \\ Faculty of Business \\ University of the Sunshine Coast \\ Sunshine Coast, Queensland, Australia \\ Email: dgray@usc.edu.au
}

\begin{abstract}
Computer systems have become commonplace in most SMEs and technology is increasingly becoming a part of doing business. In recent years, the Internet has become readily available to businesses; consequently there has been growing pressure on SMEs to take up e-commerce. However, e-commerce is perceived by many as being unproven in terms of business benefit. This research aims to determine what, if any, benefits are derived from assimilating e-commerce technologies into SME business processes. This paper presents three in-depth case studies from the Real Estate industry in a regional setting. Overall, findings were positive and identified the following experiences: enhanced business efficiencies, cost benefits, improved customer interactions and increased business return on investment.
\end{abstract}

Keywords: electronic commerce, experiences, SMEs, critical success factors

\section{INTRODUCTION}

Computer systems have become commonplace in most SMEs and technology is increasingly becoming a part of doing business. In recent years, the Internet has become readily available to businesses; consequently there has been growing pressure on SMEs to take up e-commerce. However, e-commerce is perceived by many as being unproven in terms of business benefit. Those who have undertaken e-commerce projects have had mixed results, while many are still waiting for e-commerce to demonstrate its business worth.

This study concentrates on real estate agencies as many are SMEs and are abundant on the Sunshine Coast. As the ultimate focus of this research is the experiences of SMEs in regard to e-commerce, it is logical to specifically select those real estate agencies who are using the Internet for business purposes, rather than those who are not. While this may give a somewhat biased result, the purpose of the research, which is investigating the experiences of e-commerce, should be fulfilled.

\section{LITERATURE REVIEW}

There are many affirmations that businesses should be educated on the potential of e-commerce and that managers need to become more involved in formulating and implementing e-commerce strategies (Lawrence et al 2000, Kalakota and Whinston 1997, Timmers 1999). SMEs constitute over 97 percent of nongovernment businesses in Australia (ABS 2000), consequently they contribute significantly to the economy of Australia and provide a large proportion of the public sector employment.

To assist in the understanding of the workings of electronic commerce and its applicability to SMEs, models of the activity have been examined. The current e-commerce frameworks and/or models in the literature seem to come from differing perspectives presenting a range of varying elements. Chan, E. and Swatman (1999) have developed a dynamic model of e-commerce, representative of all e-commerce types, activities and capabilities that demonstrate its performance in product and service terms. The complexity of the framework is modelled into a fluid representation of the varying viewpoints of the stakeholders as displayed in figure 1.

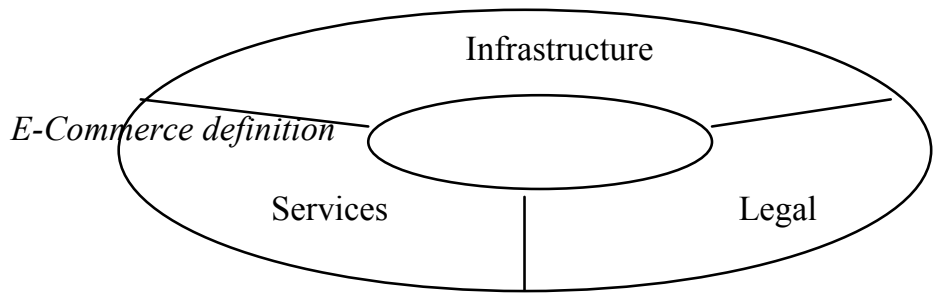

Source: Chan, E. and Swatman (1999)

Figure 1: The Meta View of E-Commerce

The meta view level is made up an e-commerce definition surrounded by three components containing various objects: Infrastructure (Technical), comprising: databases, EDI, ISP, security, web site, smart card devices, 
development multimedia, communications/telecommunications/network technologies, internet/intranet/extranet. Legal, comprising: government policy, ethics/computer crime, privacy, copyright, legal issues. Services, comprising: EFTPOS, EFT, e-publishing, e-catalogues, information kiosks, on-line shopping and education, other Internet commerce activities (Chan, E. and Swatman 1999). The three basic components: 'Infrastructure', 'Services' and 'Legal' comprise the framework of e-commerce. The boundaries are fluid; subsequently the size of each area is determined by the specific views of the parties involved. Any alteration of the borders does not affect the actual weight of the components within the model. The model also allows for changes over time as objects may be added to or removed from the basic components. While the authors state that this model needs further refining, it appears to be most effective at modelling the components, structure and dynamic nature of e-commerce. The following section details previous studies on e-commerce experiences.

\section{ECOMMERCE EXPERIENTIAL FACTORS}

A search of the literature has revealed a number of empirical studies detailing the experiences of SMEs once they have implemented an e-commerce initiative. These results are from Australian studies, with the exception of Golden and Griffin (Ireland) and Adam and Deans (Australia and New Zealand). The studies examined have determined that there are a number of common factors contributing to the experiences of SMES and their e-commerce projects.

\section{Experiential Factors - Difficulties}

A number of difficulties have been experienced by SMEs after they have initiated their e-commerce projects. These difficulties begin with ineffective planning in the e-commerce adoption stages and progress into problems with website consultants, difficulties determining the extent of Internet involvement in customer interactions, and a lack of immediate ROI. The first experiential factor is that of ad hoc adoption. A majority of the studies claimed that the SMEs investigated instigated their e-commerce initiatives using a relatively ad hoc method (Bode and Burn 1999, Boon and Hewett 2000, Castleman and Cavill 2001, Chappell and Feindt 1999, Golden and Griffin 1998, Marshall et al 2000, Poon and Swatman 1999, Singh and Fisher 1999). Consequently, most of these businesses either had no business plan or did not include e-commerce strategies in any existing business plans, nor did they re-engineer business processes for e-commerce integration.

Another issue for SMEs was dissatisfaction with website consultants. There was general dissatisfaction with web site design consultants, with many SMEs feeling that they were pressured into a site that was not a planned business initiative (Marshall et al 2000). Lawrence (1997) noted that external consultants were perceived as a 'necessary evil' who gave inappropriate and ambiguous advice and did not provide satisfactory follow-up service. In the Bode and Burn (1999) investigation of SME experiences with website consultants, the organisations felt that their individual business needs were not met. This is supported in the study by Golden and Griffin (1998) where 30 percent of SMEs stated that they were not satisfied with their website designer.

Indetermination of Internet Involvement was another factor identified. Determining if e-commerce has increased profits, reduced expenses or attracted new customers has proved problematic for many SMEs. Generally, businesses had not ascertained if their customers had used the Internet to gain information regarding the business or its products before they approached the company (Marshall et al 2000, Poon and Strom 1997). Poon and Strom (1997) explained that businesses were not able to keep records on how much the Internet increased sales or brought in business due to the difficulties of ascertaining causal relationships.

Finally, lack of return on investment (ROI) was identified by a number of the previous studies as a problematic area. They report that SMEs who have undertaken e-commerce initiatives have not experienced any immediate return on their investments (Chau and Pederson 2000, Golden and Griffin 1998, Marshall et al 2000, Poon and Strom 1997, Poon and Swatman 1999). Poon and Swatman (1999) report that Internet sales

\section{Experiential Factors - Benefits}

and on-line transactions were largely disappointing for the organisations in their study.

It has been recognised that many SMEs translated perceived benefits into competitive advantage (Drennan and Kennedy 2000, Poon 2000, Poon and Strom 1997, Yellow Pages 2000). This could be explained by the fact that e-commerce, being a new mode of business, is not utilised by every organisation. Therefore, when an SME experiences benefits, they feel they have an advantage over their non-e-commerce compliant competitors. The benefits experienced by SMEs also include enhanced communications and improved customer and business interactions. Many of these factors were also identified as initial facilitators to ecommerce adoption. 
Many of the organisations felt that the Internet had provided a strategic advantage by allowing them to be first movers or to keep ahead of customer and supplier demands (Golden and Griffin 1998, Marshall et al 2000, Poon and Strom 1997). Additionally, e-commerce implementation was seen as a necessary prerequisite by SMEs to avoid being left out if large corporations and administrations required electronic access (Singh and Fisher 1999). SMEs in general seem motivated to take up e-commerce to avoid being left out.

Perceived by SMEs as a facilitator to e-commerce adoption, access to information and communications were felt to be factors that had been enhanced through e-commerce. It was considered that the Internet provided an efficient information resource to access competitors' sites, obtain supplier information and research new markets (Golden and Griffin 1998, Marshall 2000, Poon 2000, Poon and Swatman 1999). Enhanced communications through e-mail and EDI resulted in cost savings and allowed time and geographic limitations to be overcome through the ability to conduct asynchronous communication (O'Brien and Van Akkeren 2000, Poon and Strom 1997, Poon and Swatman 1999).

Additionally, organisations studied found that e-commerce benefited their customer interactions. They believed that the Internet lowered costs and improved responsiveness as it increased organisational efficiency and produced faster reaction times to customer needs, particularly in processing orders and correspondence (Chau and Pederson 2000, Yellow Pages 2000). Also identified was the benefit to business reported to be the ability to establish a network of similar businesses that can support each other (O'Brien and Van Akkeren 2000, Swatman 2000). While support between businesses can be beneficial, as revealed in the section dealing with inhibiting factors, many SMEs are reluctant to share knowledge or information as it is felt that this could threaten their competitive advantage (Love et al 1999).

Finally, despite the difficulties experienced by many organisations, most seem firmly convinced that the Internet has potential for their businesses in the future (Chau and Pederson 2000, Golden and Griffin 1998, Marshall et al 2000, Poon and Strom 1997, Singh and Slegers 1999). While many SMEs had experienced marginal savings or earnings from the Internet, they resolved to continue their Internet use even though it was difficult to justify in terms of immediate ROI.

\section{Critical Success Factors}

In comparing the experiential factors with the critical success factors, one particular issue from both areas is mentioned by a majority of authors. Most businesses seem to approach e-commerce projects in a somewhat ad hoc manner with no clear e-commerce strategies. Many adopt e-commerce, but do not incorporate it into the processes of the business. As Golden and Griffin (1998) observed, in hindsight many SMEs regretted the omission of e-commerce from business processes. Hence the most noted critical success factor recommends that if an organisation is committed to an e-commerce project, it a greater chance of success if e-commerce is integrated into business practice. Other success factors included the encouragement of customers or business partners to use e-commerce, a unique or innovative product or service will be more successful, and that support can be obtained from other like-minded businesses. The research suggested that competent use of technology combined with an effective web site would ensure that the expenditure on these facilities was justified. If SMEs are aware of these factors, their e-commerce initiatives may be more likely to eventuate in financial benefit and enhanced customer interactions.

The authors of the studies reviewed conclude that had the businesses they researched been aware of the various factors critical to success, the businesses would have had greater chance of success in their ecommerce ventures. One of the aims of the current study is to determine if this is in fact the case.

\section{RESEARCH DESIGN}

This study involved the use of interpretive research methods to conduct hermeneutic field studies with the aim of discovering participant's beliefs, actions and experiences with e-commerce in their place of work, that is, real estate agencies. Benbasat, Goldstein and Mead (1987) advocate the use of a case research strategy for studying information systems in a natural setting to gain an understanding of the nature and complexity of the situation and to research an area with fewer previous studies. Walsham (1995) argues that, particularly in interpretive studies, outside observers derive their information chiefly from interviews. He states that interviews are the richest form of case study data as they provide the most comprehensive coverage of the of participants' interpretation of actions and events in the past or present and the views and aspirations of themselves and others.

Given the objective of this research, real estate agencies that utilise some form of e-commerce were selected to ensure that the owner/managers of these organisations could provide some comment on their experiences with conducting business over the Internet. Real estate agencies were selected as the specific field of research for this study as this industry has adopted e-commerce with relative enthusiasm. Many utilise not only e-mail, 
but also have a web presence. This is important to the research as the experiences of SMEs since their adoption of e-commerce is a prime focus of this investigation. Rich data was collected from the organisations through conducting multiple case study research in the form of field studies. Interviews were conducted with three real estate agencies to gain insight into their use of e-commerce.

The interviews commenced with broad questions. As the interview progressed, participants were prompted to provide information according to a pre-defined topic list. As Eisenhardt (1986) recommends, specifying constructs a priori assists in the more accurate measurement of concepts. The interviews aimed at surfacing issues relevant to the individual organisations, thereby supplying rich data that is provided freely and spontaneously by the participants (Sekaran 1992, Moutinho et al 1999). As advocated by Walsham (1995) the interviews were tape recorded on a micro cassette recorder (with the permission of the participants), thus providing a full account of all that is said during the interview. The recordings were supplemented with notes, which included important points or additional observations or impressions taken by the researcher. Once the data has been collected, it was examined for themes, patterns and meanings within and between the organisations.

\section{FINDINGS}

This section analyses the information collected from the three interviews. These interviews assisted in providing preliminary findings by raising pertinent issues. Three real estate organisations with differing types of web presences were selected. The aim of this approach was to facilitate the development of a comprehensive course of action for the main phase of the research. To assist in conducting a clear discussion and to comply with ethical guidelines, the cases will be referred to as case A, case B and case C. These field studies are briefly described in Table 1 .

\begin{tabular}{|l|l|l|l|l|l|}
\hline $\begin{array}{c}\text { Field } \\
\text { Stu } \\
\text { dy }\end{array}$ & Services & $\begin{array}{c}\text { Years Business } \\
\text { in } \\
\text { Operation }\end{array}$ & $\begin{array}{c}\text { Years of Current } \\
\text { Owner/Mana } \\
\text { ger }\end{array}$ & $\begin{array}{c}\text { Number of } \\
\text { Employ } \\
\text { ees }\end{array}$ & $\begin{array}{c}\text { Type of Web } \\
\text { Presence }\end{array}$ \\
\hline CaseA & $\begin{array}{c}\text { Property } \\
\text { sales, } \\
\text { rentals }\end{array}$ & 52 & 5 & 9 & $\begin{array}{c}\text { Own domain web } \\
\text { site }\end{array}$ \\
\hline CaseB & $\begin{array}{c}\text { Property } \\
\text { sales, } \\
\text { rentals }\end{array}$ & 29 & 2.5 & 44 & $\begin{array}{c}\text { Franchised agency } \\
\text { group sub-site }\end{array}$ \\
\hline CaseC & $\begin{array}{c}\text { Property } \\
\text { sales, } \\
\text { rentals }\end{array}$ & 30 & 6 & 5 & $\begin{array}{c}\text { Real estate portal } \\
\text { sub-site }\end{array}$ \\
\hline
\end{tabular}

Table 1: Field Study Details

These interviews occurred from September to October 2001 on the Sunshine Coast in Queensland. The interviews were conducted with the owners/managers of the three real estate agencies. All the interviews were approximately one hour in duration and were taped on a micro cassette recorder. The cases are discussed in line with the areas of research, that is: e-commerce experiences and e-commerce success contributors. Preceding these points for each case is a brief description of the organisation.

\section{Case A - Own Domain Web Site}

Case $A$ embarked on its Internet presence with a one-page web site with its own domain name, containing contact information and email links. One year ago, this was upgraded to quite a comprehensive web presence, where clients can access a wide range of information through numerous pages within the site. The property listings on the site are updated daily and take the form of sales and rentals (both residential and commercial). These are accessed through an internal link within the frame of the agency's site to realestate.com, a portal with comprehensive real estate search facilities. The site adds value for the customer in the form of a property search facility, loan calculator and information about the Sunshine Coast. The site also contains email links and a form where clients can electronically list a property with the agency.

\section{Negative experiences with e-commerce.}

The owner expressed a discontent with outside consultants. He felt that there are many consultants in the industry who cannot be trusted: 
"There is an enormous amount of 'shonks' in this industry"

He stated that often the business does not always get what it wants or needs from these consultants. The business, to date has not experienced a return on its initial investment. However, the owner stresses that the cost of maintaining the site each year was not a large financial burden as it is roughly the profit on only one sale (approximately \$5000). Moreover, the owner firmly believes in the future potential of his e-commerce project:

"Judging by the last six months, by the end of this year it will be returning dividends."

\section{Positive experiences with e-commerce.}

The owner maintained that e-commerce has greatly enhanced the efficiency of his business and had delivered cost-benefits and time-savings by providing instant access to on-line resources such as property information and tenant checking. He stated:

"That's one way our office has changed for the better, it's more streamlined. The efficiencies are paying off.

We can source the information we need, start a task, get the information, finish the tasks, put it to bed."

The agency has gained new customers, some international, through the greater market penetration facilitated by the web site. The owner believes that the web site has enhanced customer interactions through allowing customers to conduct their own research on available properties. Customer relationships have also been enhanced by the agency replying to emails immediately, with customer feedback such as:

$$
\text { "I got onto twenty agents, you're the only guy who got back to me." }
$$

\section{E-commerce success contributors.}

The e-commerce adoption facilitator of customer demand ensured that the agency had a critical mass of customers to provide their service over the Internet. The owner's determination to persevere with ecommerce despite having setbacks with IT/web site contractors is undoubtedly one of the main contributors to the relative success of the e-commerce venture for this agency. An additional facilitator to the success of the e-commerce venture was the owner's strong motivation and commitment to e-commerce:

$$
\text { "If I'm going to do it, I'll make sure that it works." }
$$

It appears that the owner's high confidence level with technology and the Internet also helped in this respect as he spent a great deal of time working out problems himself and then training the staff:

"There is a wealth of information. I am going to control it, it is not going to control me."

The owner clearly recognises the value of information to the firm and how being in control of it can enhance his business.

A further contributor to the success of the e-commerce initiative has been the incorporation of e-commerce into the processes of the business. This is evident through the use of the on-line property and tenant checking systems and the use of the Internet for research. Additionally the owner feels that producing a high standard of e-commerce presence has encouraged customers to continue to use this agency's e-commerce and which thus ensures its continued success. Interestingly, the owner stated that he had not had a formal plan or specific strategy for his e-commerce initiative.

\section{Case B - Sub-site of Franchised Agency Group}

Overview and status. Case $B$, as part of a franchised real estate group, has a two-page web presence located as a sub-site of the parent organisation's site. The site, established in 1994, contains a search facility that can link to properties specifically listed with this agency or to the wider franchise group properties. The site is accessed through the parent company's web site and is not easy to locate. The agency does not have its own domain name. The Sunshine Coast offices have forty-four staff, most with computers and Internet access. They utilise Internet technologies such as email, Internet banking, accessing legislation, the Australian Bureau 
of Statistics, the tenants registry (Ticker) the parent company website and secure site for updating. The agency handles commercial and residential sales and rentals.

\section{Negative experiences with e-commerce.}

The owner feels that with regard to e-commerce, that:

$$
\text { "There's a lot more down sides than positives." }
$$

When asked if he had experienced a return on his investment, the owner replied:

"Absolutely not. It's only because its high maintenance, it's so prolific the way it grows, the way it changes... every six months. For us its probably just been an extra $\$ 30,000-\$ 40,000$ cost."

The owner explained that due to e-commerce, there are problems with staff technical skills:

"It's because the computer programs in any sort of business have become so specialised, when you have a girl leave or go on holidays, it's an extra cost to having someone come in who understands that particular program."

The agency does get email enquiries initiated from their Internet presence. However, the owner states that regarding daily property enquiries, they may get twenty phone calls, but only five emails. The owner does not view this as creating more business for his agency, but states that this demonstrates that a web site is no more effective in generating interest than traditional methods. He felt that the web site played only a small role in the marketing of the agency:

"Having properties on the Internet, to my mind, is just like having another sign in the marketplace, having another ad in the paper or having another window card."

Real estate, according to the owner, is not really suited to sales over the Internet:

$$
\text { “We get a lot of enquiry off the Internet but we don't make a lot of sales from it." }
$$

The owner felt that it was hard to determine if a sale was due to the client initially accessing property information from the web site. He likened it to a customer finding a property advertised in the newspaper, visiting the open house and deciding to buy the property - the sale could not be attributed to any one factor.

"Initially, it makes it easier for them to access us but at the end of the day, when they're going to buy property, they're going to be here in person anyway."

Like case A, this agency also has weekly approaches from web site development contractors about setting up a site. This agency had not had any feedback from customers, nor had the agency asked for any feedback.

\section{Positive experiences with e-commerce.}

The owner nominated a number of benefits, in terms of customers, to having e-commerce:

"On the sales side of things, we're probably accessing more of a market."

The agency has also been able to enhance customer interactions by emailing details and photos of rental property inspections to owners who are not in the area.

"I think at the end of the day people will find you but it has made it easier for us to retain people from overseas."

The owner was convinced that internal business operations was where e-commerce was most worthwhile, but continued to state that the benefits of e-commerce were outweighed by its expenses and disappointments:

"Definitely on the business side of business, is a lot easier to just have that one girl being able to handle the pays and that sort of thing. But it costs to have those programs as well. " 
The owner believes that the Internet has made researching information more straightforward. However, the owner considers that the expense incurred has not justified the outlay:

"It's great for research, and it's probably easier, but there is a price to be paid for being easy. It's much the same as when mobile phones came in. All they did was double the phone bills of businesses."

\section{E-commerce success contributors.}

The owner felt that to be successful in e-commerce, it was important to be cautious and not take on new technology until it is thoroughly tested. This belief is clearly at odds with the first mover philosophy of the company CEO.

\section{"Be careful not to be the cutting edge. It's good to be at the cutting edge. It's good to have all the technology. But don't be out there experimenting with things."}

He felt that the success of his e-commerce project was obvious in the internal functions of the organisation and in enhancing B-2-B interactions, rather than in sales or marketing:

"I think it's been a success more from running the business as opposed to promoting the business and creating the business. Inside the business it's been great, there's no doubt about that".

Ultimately, the owner felt that the main benefit of e-commerce for his organisation was through facilitating internal business operations. The owner believed that e-commerce proved to be worthwhile and valuable in the area of increased business efficiency. However, he believed that these benefits were outweighed by the expense, extra work and inconvenience of e-commerce.

\section{Case C - Sub-site of Real Estate Portal}

Overview and status. Case $C$ is an agency with five staff and is run by the owner. The agency has been operating for thirty years; the current owner has owned the business for six years. As with the previous two cases, the owner perceives that all of his competitors use e-commerce. He upgraded the existing computer system, which seemed to consist of one centrally located computer, for the instigation of e-commerce. The agency uses e-commerce for email, tenancy checking through Ticker, Internet banking and accessing legislation.

\section{Negative experiences with e-commerce.}

The owner felt that his business had changed since the advent of e-commerce and that sometimes Internet technology provided too many options, leading to a feeling of being overwhelmed, thereby threatening his control of the situation.

“It's a lot faster now, it's more complex. Now, there's a lot more options. I think people expect a lot more services and that's why you've got to keep up with the times. Things are changing so quickly now with the equipment-I don't know where it's going to end."

Overall, the owner did not seem content with changes brought about by e-commerce.

"The industry is changing rapidly, the workload is double what it used to be. Now that it [e-commerce] is about, there are more services that we must provide to stay competitive. It's very good for us to have, too, but we're working a lot harder'.

The owner has not received any feedback from his customers regarding his e-commerce initiatives. He did not experience any unforseen benefits from e-commerce as others in the real estate industry had told him what to expect.

\section{Positive experiences with e-commerce.}

The owner believed that e-commerce had enhanced customer enquiry: and become more of an industry standard: 
Certainly our industry, over the last five years has definitely changed. It's been good for us too, we've got a lot of enquiry from that site that we would never have had."

He does use the Internet to conduct research such as checking on competition and states that:

"Its regularly updated and it's a great source of information."

According to the owner, he has experienced a return on his investment in adopting e-commerce because he did not spend a large amount of money:

“We haven't gone overboard with it, just kept up with the times. Business is building and this is definitely partly due to e-commerce."

As a form of marketing, the owner believes that e-commerce has worked quite well for his business.

\section{E-commerce success contributors.}

The owner considers that his e-commerce venture has been successful and ascribes this to the fact that he waited to see what his competitors did, demonstrating that first mover advantage was irrelevant to him. He feels he had the time to then conduct his e-commerce initiative effectively. He stated that:

\footnotetext{
“We didn't rush into it. We weren't the first doing it, by far. But when we had it up and running, we were using it to its best advantage."
}

This restrained uptake could also be attributed to the owner's lack of technical knowledge in not realising the possible benefits of e-commerce to his business. An additional success contributor was the education he received from the seminar conducted by the technology and website development organisation. The owner felt that the seminar had taught him valuable information about the Internet, and allowed him make more informed decisions, facilitating a sense of control and commitment. He was also very happy with the contractor service that he received in setting up his web presence.

\section{SUMMARY}

The experiential issue data has from the three field studies has been analysed and is now summarised. The negative experiential factors of e-commerce varied, with a number of negative experiences not evident in the literature emerging from the interviews. Firstly, staff with specialised skills were required; secondly, the workload of the business had increased; and finally, there was a lack of perceived benefits from e-commerce. There were several positive experiential factors associated with e-commerce which were common to cases A, $\mathrm{B}$ and $\mathrm{C}$ : the ability to access on-line resources for research; improved interactions with customers; better penetration of the local marketplace; and enhanced efficiency within the business.

Although not commonly noted in the literature, all of the organisations utilised B-2-B interactions such as Internet banking, tenant checking and legislation access through the Internet. This, along with the use of email was seen as improving the efficiency of their business. Two positive experiences that did not appear in the literature surfaced from the interviews. Case A identified that the efficiencies that e-commerce had created in the workplace had resulted in the staff being more contented and having lower stress levels. Both cases $\mathrm{A}$ and $\mathrm{C}$ stated that they had experienced an increase in business since their uptake of e-commerce. Interestingly, while cases $\mathrm{A}$ and $\mathrm{C}$ perceived future e-commerce benefits would be experienced, case B did not believe that e-commerce would produce any further benefits to his agency in the future. However, due to pressure from the parent company, he seemed to feel compelled to continue its use.

A number of the factors shown in the literature review to be inhibitors to e-commerce adoption manifested as actual negative experiences by the real estate agencies. They are: poor experiences with IT consultants; lack of ROI; lack of perceived benefits; and increased staff workload.

Likewise, various e-commerce adoption facilitators identified in the literature emerged as positive experiential factors for the cases studied. They are: enhanced business efficiency; cost benefits; improved customer interactions; and increased business ROI. This demonstrates that organisations are becoming more informed about the relevant issues likely to impact on their businesses before they adopt the relatively new business process of e-commerce. 


\section{Critical E-commerce Success Factors}

The owners in each of the cases A, B and C perceived a number of contributors to e-commerce success. All of the agencies had a service that could be provided over the Internet. Each agency had been able to source a competent consultant and had incorporated e-commerce into their business processes. All of the cases had incorporated e-commerce into their businesses to some extent, most commonly through the use of email and B-2-B interactions. Although B-2-B dealings such as Internet banking, tenant checking and accessing legislation were cited as being a factor in the literature regarding e-commerce experiences, this was not revealed in the literature as a contributing success factor for e-commerce. In fact, case B nominated this factor as the most successful aspect of e-commerce, as his agency's on-line presence had not met his expectations regarding increased sales.

Other noted contributors to the success of e-commerce that were not found in the literature were: effective web site promotion; taking a cautious, wait and see approach and not utilising unproven business applications; and continued customer use of e-commerce. One issue that was noticeable by its omission was that none of the organisations went into e-commerce with a formal plan or a defined business case with clear objectives. They all simply allowed the project take its own course. The owners all learnt along the way from their own or others' experiences. This seems to be consistent with the manner in which many small businesses function.

\section{CONCLUSION}

Findings from this preliminary study have identified e-commerce experiences by SMEs in the real estate sector. It has resulted in preliminary findings that can be used for further in-depth research into e-commerce experiences and critical success factors (CSFs).

The findings have been informed from the literature on e-commerce experiences and CSFs, as well as the three in-depth field studies undertaken. In many ways, this study raises many questions and has implications for further research in this important field. It would be useful to undertake further field/case studies in the real estate sector to improve the rigour of the findings. In addition, broadening the SME industry sectors would also help to improve the generalisability. A comparison between other regional area in Australia, or replication in other metropolitan areas would also provide an important contribution to this area of research. However, findings from this research make both theoretical and practical contributions to IS literature. In practical terms, IS professionals and SME owner/managers can learn from the findings and improve strategic planning and assimilation techniques. Theoretically, researchers in this field of study have a basis to undertake further research to more clearly identify lessons learnt, experiences and CSFs in e-commerce adoption and assimilation.

\section{REFERENCES}

ABS (Australian Bureau of Statistics), 2000, 8129.0 Business Use of Information Technology Australia, [on-line], http://www.abs.gov.au/ausstats/ABS\%40.nsf/b06660592430724fca2568b5007b8619/9c7742890adec989c a2568a900139423! OpenDocument, accessed 15 May 2001.

Adam, S. and Deans, K. R., 2000, “On-line Business in Australia and New Zealand: Crossing a Chasm”, Ausweb2K Sixth Australian World Wide Web Conference, Southern Cross University, Lismore, [on-line], http://www.ausweb.scu.edu.au/aw2k/papers/adam/paper.html, Accessed 7 June 2001.

Benbasat, I., Goldstein, D. K. and Mead, M., 1987, "The Case Research Strategy in Studies of Information Systems", MIS Quarterly, vol 11, issue 3, pp 369-387, September.

Bode, S., and Burn, J., 1999, "SMEs and the Role of Consultants in Establishing e-business: A Case Analysis", Proceedings of CollECTeR '99, Victoria University, New Zealand, [on-line], http://www.collecter.organisation/coll99/bode.pdf, accessed 17 March 2001.

Boon, O. and Hewett, W. G., 2000, Requirements Gathering in Implementing a Web Presence: A study of the Warrnambool Region Initiative, School of Management Information Systems, Faculty of Business and Law, Deakin University, [on-line], http://mis.deakin.edu.au/research/Working_Papers_2000/2000_11_Hewett.pdf, accessed 19 March 2001.

Castleman, T. and Cavill, M., 2001, "e-Everything: e-Commerce, e-Government, e-Household, eDemocracy", Proceedings of the 14th Bled Electronic Commerce Conference, Bled Slovenia, June 2526, [on-line], http://mis.deakin.edu.au/research/Working_Papers-2001/2001 02 Castleman.pdf, accessed 27 June 2001. 
Castleman, T., Swatman, P., and Swatman, P. M. C., 2000, The Role of Government in Internet Commerce: Views from the [on-line], http://mis.deakin.edu.au/research/Working_Papers-2000/2000_09_Castleman.pdf, accessed 6 May 2001.

Chan, E. and Swatman, P. M. C., 1999, "Electronic Commerce: A Component Model", Proceedings of CollECTeR '99, Victoria University, New Zealand, http://www.collecter.organisation/coll99/elsiechan.pdf, accessed 17 March 2001.

Chappell, C. and Feindt, S., 1999, "Analysis of E-commerce practice in SMEs", Knowledge and Information Transfer on Electronic Commerce (KITE), European Union On-line, [on-line], http://europa.eu.int/ISPO/e-commerce/sme/reports/kitebsetpractice.doc, accessed 9 April 2001.

Chau, S. and Pederson, S., 2000, "The Emergence of New Micro Businesses Utilising Electronic Commerce", Proceedings of the $\mathbf{1 1}^{\text {th }}$ Australian Conference of Information Systems (ACIS), Cable, G. G. and Vitale, M. R. (eds), Brisbane, [CD-ROM].

Drennan, J. and Kennedy, J. (2000) "Internet acceptance and use by small firms: A study of the pharmacy sector", Conference Proceedings of $\mathbf{4 5}^{\text {th }}$ ICSB World Conference, Brisbane, 7-10 June [CD-ROM].

Eisenhardt, K. M., 1989, "Building Theories from Case Study Research", Academy of Management. The Academy of Management Review, October, vol 14, issue 4, pp 532-551.

Golden, W. and Griffin, M., 1998, A Survey of Internet commerce in small and medium enterprises, National University of Ireland, [on-line], http://www.nuigalway.ie/acc/staff/wgolden/aurvey/survey_report.htm, accessed 23 April 2001.

Kalakota, R. and Whinston, A. B., 1997, Electronic Commerce: a Manager's Guide, Addison Wesley Longman, Inc, USA.

Lawrence, E., Corbitt, B., Tidwell, A., Fisher J., and Lawrence J. R., 2000, Internet Commerce: Digital Models for Business, John Wiley \& Sons Australia Ltd, Brisbane.

Lawrence, K. L., 1997, "Factors inhibiting the utilisation of electronic commerce facilities in Tasmanian small- to medium-sized enterprises", $8^{\text {th }}$ Australasian Conference on Information Systems, October.

Love, P. E. D., Irani, Z., Warren, M., Coldwell, J. and Warren, S., (2000), "Barriers to implementing Ecommerce in construction SMEs", ANZAM Conference, Sydney, Australia, Dec 3-6, [online], http://www.gsm.mq.edu.au/conferences/2000/anzam/Archive_pap\&abst/fullpaper_frameset.html, accessed 10 May 2001 .

Marshall, P., Sor R. and McKay, J., 2000, "Electronic Commerce and Car Retailing: An Industry Case Study”, International Journal of Electronic Commerce Research, vol 1, no1.

Moutinho, L., Goode, M. and Davies, F., 1999, Quantitative Analysis in Marketing Management, John Wiley, Brisbane.

O'Brien, P. and Van Akkeren, J., 2000, "The Effectiveness of Project-Assisted Adoption of e-commerce by Small Businesses in the Tourism Industry", Conference Proceedings of $45^{\text {th }}$ ICSB World Conference, Brisbane, 7-10 June [CD-ROM].

Poon, S., 2000, "Business environment and Internet commerce benefit - A small business perspective", European Journal of Information Systems, June, vol 9, issue 2, pp 72-81, [ABI Inform].

Poon, S., and Strom, J., 1997, "Small Businesses' Use of the Internet: Some Realities", Proceedings of the Seventh Annual Conference of the Internet Society (INET 97), The Internet: The Global Frontier, Kuala Lumper, June 24-27, [on-line], http://www.isoc.org/inet97/proceedings/C2/C2 1.HTM, accessed 4 June 2001.

Poon, S. and Swatman, P. M. C., 1999, "An exploratory study of small business Internet commerce issues", Information \& Management, Jan, vol 35, issue 1, pp 9-18, [ABI Inform].

Sekaran, U., 1992, Research Methods for Business: A Skill Building Approach, $2^{\text {nd }}$ Edition, John Wiley \& Sons, Inc, USA.

Singh, M. and Fisher, J., 1999, "Electronic Commerce Issues: A Discussion of Two Exploratory Studies", Proceedings of CollECTeR 99, Victoria University, New Zealand, [on-line], http://www.collecter.organisation/coll99/singh.pdf, accessed 17 March 2001.

Singh, S., and Slegers, C., 1998, The Story of Small Business and Electronic Commerce, Centre for International Research on Communication and Information Technologies (Circit), RMIT, Melbourne.

Swatman, P., 2000, “Internet for SMEs: A new skill road?” International Trade Forum, Geneva, Issue 3, pp 22-24, [ABI Inform].

Timmers, P, 1999, Electronic Commerce: Strategies and Models, for Business-to-Business Trading, John Wiley \& Sons Ltd, England.

Walsham, G., 1995, 'Interpretive case studies in IS research: nature and method', European Journal of Information Systems, vol 4, issue 2, pp74-81. 
Yellow Pages Australia, 2000, Small Business Index: Survey of Computer Technology and E-Commerce in Australian Small and Medium Businesses, Telstra Corporation Limited and the National Office for the Information Economy, Australia, June.

\section{COPYRIGHT}

Diana Gray and Jeanette Van Akkeren (C) 2002. The authors assign to ACIS and educational and non-profit institutions a non-exclusive licence to use this document for personal use and in courses of instruction provided that the article is used in full and this copyright statement is reproduced. The authors also grant a non-exclusive licence to ACIS to publish this document in full in the Conference Papers and Proceedings. Those documents may be published on the World Wide Web, CD-ROM, in printed form, and on mirror sites on the World Wide Web. Any other usage is prohibited without the express permission of the authors. 